\title{
THE AUSTRIAN INTEGRATION ACT 2017
}

\author{
MICHAEL GEISTLINGER
}

\begin{abstract}
The short study on the Austrian Integration Act 2017 does not focus on the link between the Austrian Integration Act 2017 and the sanctions directly or indirectly linked to its violation based on other laws in effect in Austria, but on the understanding of the concept and term of "integration" with the help of analyzing the means of providing for "integration". It is shown that the definition of integration clearly expresses a monoculturalist approach as opposed to a multiculturalist, both in the understanding of the theory of Bhikhu Parekh, and results from a multitude of cultural communities in Austria as a consequence of migration processes. The definition of integration addresses these groups from the point of view of their integration into the Austrian society. It does not deal with obligations or behavior on the other side, the side of the receiving society. It, thus, is a desideratum for a sustainable approach to adapt the measures for and policies of integration to its underlining concept which says that integration is a "reciprocal process". In order to be successful, the role of both sides should be considered.
\end{abstract}

Keywords: foreign nationals; integration; migration; citizenship; integration policy

Klíčová slova: cizinci; integrace; migrace; státní občanství; integrační politika

DOI: $10.14712 / 23366478.2018 .8$

\section{SOME REMARKS ON THE GENESIS OF THE AUSTRIAN INTEGRATION ACT 2017}

The Austrian Integration Act $2017^{1}$ has its roots in provisions on integration which were first introduced in $2002^{2}$ and were specified and expanded in 2005 within the framework of the largest reform of the Austrian laws on aliens, stateless persons and refugees since 1997. The reform of the Austrian Aliens Act in 2002 introduced the "integration agreement" as a measure to oblige residents from non-EU countries to acquire basic knowledge of the German language in order to become capable of participating in the social, economic and cultural life in Austria. This capacity could be acquired by attending a German-Integration-course ( $§ 50$ a paras 1 and 2 Austrian Aliens Act 1997 as amended in 2002). From the very beginning, failure to attend this course was sanctioned by non-issuance of a certificate to stay ( $\$ 24$ Austrian Aliens Act 1997 as amended in 2002), by eventual expulsion ( $\$ 34$ paras 2a and 2b Austrian Aliens Act

1 Full title: Federal Act for the Integration of Persons without Austrian Nationality Legally Resident in Austria (Integration Act), BGBl (Federal Law Gazette). I Nr. 68/2017, as amended by BGB1. I Nr. 86/2017.

2 Inclusion of $\S \S 50$ a-d and of $\S \S 14$ paras 3 a and b Austrian Aliens Act (Fremdengesetz) 1997 by BGB1. I Nr. 126/2002. 
1997 as amended in 2002) and by a fine as a consequence of an administrative offence ( 108 paras 1a and 1b Austrian Aliens Act 1997 as amended in 2002).

The Austrian Integration Act 2017 did not replace these other acts dating from 2005, which are the Austrian Asylum Act 2005, ${ }^{3}$ the Austrian Aliens Police Act $2005^{4}$ and the Austrian Settlement and Residence Act 2005. 5 Thus, these acts and the measures of a sanction character laid down by them, continue to be in place and have to be considered in the context of the Austrian Integration Act 2017. This short study will, however, not focus on the link between the Austrian Integration Act 2017 and the sanctions directly or indirectly linked to its violation, but on the understanding of the concept of "integration" with the help of analyzing the means of providing for "integration".

The Austrian Asylum Act 2005 dates back to 1997, ${ }^{6}$ was fundamentally revised in $2003^{7}$ and was issued as a new act, after the Austrian Constitutional Court had annulled some provisions of the previous act. ${ }^{8}$ Already the Asylum Act 1997 included a provision on assistance to integration ( $\S 41)$, which was not amended, but became $\S 68$ in 2005 . The wording was nearly identical.

$\S 68$ Asylum Act 2005 defined as integration for aliens entitled to the status of asylum (refugees according to the Geneva Convention relating to the Status of Refugees) "their full inclusion into the Austrian economic, cultural and social life and as much as possible equality of chances with Austrian citizens in these areas". There was no obligation laid down for the Austrian government to provide for such integration assistance and, thus, also no respective right for the refugee. The assistance "could be granted". Measures enumerated by this provision were language courses, courses on education and continuing education, events on introduction into the Austrian culture and history, joint events with Austrian citizens for promotion of mutual understanding, passing on of information on the housing market and benefits of the Austrian Integration Funds (§ 68 para 2 , numbers $1-6$ ).

The provisions on integration included into the other two acts dating from 2005 (§ 54 Austrian Aliens Police Act 2005 and $\S \S 14-18$ Austrian Settlement and Residence Act 2005) must be seen primarily in the context of the Directive of the Council of the EU 2003/109/EC concerning the status of third-country nationals who are longterm residents. ${ }^{9}$ Number 4 of the Preamble to this Directive declares the integration of third-country nationals who are long-term residents in the Member States " $a$ key element in promoting economic and social cohesion, a fundamental objective of the Community stated in the Treaty". This reasoning is the same as already included in the Directive of the Council of the EU 2003/86/EC of 22 September 2003 on the right to

\footnotetext{
BGBl. I Nr. 100/2005.

BGBl. I Nr. 100/2005.

BGBl. I Nr. 100/2005.

BGB1. I Nr. 76/1997.

BGBl. I Nr. 101/2003.

Annulments promulgated BGBl. I Nr. 105/2003 and BGBl. I Nr. 129/2004.

OJ L 16, 23/1/2004 P. 44-53. Number 4 of the Preamble reads as follows: "(4) Family reunification is a necessary way of making family life possible. It helps to create sociocultural stability facilitating the integration of third country nationals in the Member State, which also serves to promote economic and social cohesion, a fundamental Community objective stated in the Treaty."
} 
family reunification. ${ }^{10}$ The reform of the aliens law 2005 further referred to the Directive of the Council of the EU 2004/83/EC of 29 April 2004 on minimum standards for the qualification and status of third country nationals or stateless persons as refugees or as persons who otherwise need international protection and the content of the protection granted. ${ }^{11}$ This directive referred in number 30 and 36 of the Preamble and in Article 33 to integration.

Last but not least, the conclusions of the Council of the EU in Brussels of 19 November 2004 on "Immigrant Integration Policy in the European Union"12 have sponsored the wording of the Austrian provisions and been particularly mentioned in the Report of the Austrian Government explaining the reasons for the reform to the Austrian Parliament. ${ }^{13}$ In number 1 of the Annex to these conclusions, the Council of the EU defined integration as "a dynamic, long-term, and continuous two-way process of mutual accommodation," and not as "a static outcome. It demands the participation not only of immigrants and their descendants but of every resident. The integration process involves adaptation by immigrants, both men and women, who all have rights and responsibilities in relation to their new country of residence. It also involves the receiving society, which should create the opportunities for the immigrants'full economic, social, cultural, and political participation. Accordingly, Member States are encouraged to consider and involve both immigrants and national citizens in integration policy, and to communicate clearly their mutual rights and responsibilities."

The Council of the EU in these conclusions enumerated 10 principles to be followed by the Member States in order to achieve integration of immigrants:

"- Integration implies respect for the basic values of the European Union.

- Employment is a key part of the integration process and is central to the participation of immigrants, to the contributions immigrants make to the host society, and to making such contributions visible.

- Basic knowledge of the host society's language, history, and institutions is indispensable to integration; enabling immigrants to acquire this basic knowledge is essential to successful integration.

- Efforts in education are critical to preparing immigrants, and particularly their descendants, to be more successful and more active participants in society.

10 OJ L 251, 03/10/2003 P. 0012-0018.

11 OJ L 304, 30/09/2004 P. 0012-0023.

12 C/04/321, 14615/04 (Presse 321). Available at: http://europa.eu/rapid/press-release_PRES-04-321_en.htm (05022018).

13 Regierungsvorlage zum Fremdenrechtspaket 2005 (Explanatory Report to the Government's Draft Aliens Law Package 2005), Blg. 952 XXII. GP. See, in particular, the explanations with regard to the Austrian Settlement and Residence Act 2005, which emphasize that the revision and quantitative and qualitative expansion of the integration agreement have been one of the main goals of the reform (pp. 11 and 13). The knowledge of the German language is assigned absolute priority so that the residents shall be capable of participating in the Austrian social, cultural, and economic life. Administrative sanctions and other restrictive measures are intended to provide effectivity of the integration agreement. The draft calculates 75 course hours per person for learning the basics ("alphabetization courses", module 1) and 300 course hours per person for courses for social and cultural integration) (see p. 26). Available at: https://www .parlament.gv.at/PAKT/VHG/XXII/I/__00952/index.shtml (05022018). 
- Access for immigrants to institutions, as well as to public and private goods and services, on a basis equal to national citizens and in a non-discriminatory way is a critical foundation for better integration.

- Frequent interaction between immigrants and Member State citizens is a fundamental mechanism for integration. Shared forums, inter-cultural dialogue, education about immigrants and immigrant cultures, and stimulating living conditions in urban environments enhance the interactions between immigrants and Member State citizens.

- The practice of diverse cultures and religions is guaranteed under the Charter of Fundamental Rights and must be safeguarded, unless practices conflict with other inviolable European rights or with national law.

- The participation of immigrants in the democratic process and in the formulation of integration policies and measures, especially at the local level, supports their integration.

- Mainstreaming integration policies and measures in all relevant policy portfolios and levels of government and public services is an important consideration in public-policy formation and implementation.

- Developing clear goals, indicators and evaluation mechanisms are necessary to adjust policy, evaluate progress on integration and to make the exchange of information more effective."

$\S 54$ para 3 of the Austrian Aliens Police Act 2005, in the original version of the act, did not provide for any terminological clarification but addressed the most severe sanction for aliens from non-EU countries entitled to residence in Austria who failed to fulfill the integration agreement. Based on this provision, they could be expelled from Austria if they did not implement the integration agreement within five years after their first permit of stay because of reasons exclusively caused by them and under condition that the facts of their case justified the assumption that they were not ready to acquire the capacity to participate in the social, economic and cultural life in Austria. The protection of the right to private life and family was to be considered. The provision has been re-arranged and amended later, in particular by the aliens law reform 2011. ${ }^{14}$ On 1 January $2014,{ }^{15}$ subsequent to the inclusion of $\S 14$ a into the Austrian Settlement and Residence Act 2005, which amendment had entered into force on 1 July 2011, ${ }^{16}$ by means of $\S 52$ para 4 number 5 Austrian Aliens Police Act 2005, a link was created between module 1 of the integration agreement and the decision on return. Such decision on return must be adopted by the Federal Aliens Authority, if module 1 of the integration agreement has not been fulfilled in time because of reasons exclusively within the sphere of responsibility of the non-EU country resident.

As to terminological issues in the context of integration, the Austrian Aliens Police Act 2005 refers to the Austrian Settlement and Residence Act 2005. In this act originally $\S \S 14,15,16,17$, and 18 were the most relevant provisions, from 2014 onwards joined

14 BGBl. I Nr. 38/2011. The following is also important: Fremdenbehördenneustrukturierungsgesetz (FNG) (Act on Restructuring of the Aliens' Authorities), BGB1. I Nr. 87/2012.

15 BGBl. I Nr. 87/2012.

16 BGBl. I Nr. 38/2011. 
by $\S \S 14 \mathrm{a}$ and $14 \mathrm{~b}$. All these provisions became ineffective with the adoption of the Austrian Integration Act 2017. This goes also for $\S \S 17$, dealing with a facultative promotion and funding of integration for aliens entitled to residence, but not obliged to integration, by the Austrian Integration Fund, and 18, dealing with the Advisory Committee on Integration. The provisions of the Austrian Settlement and Residence Act 2005 not in force anymore had laid down the instrument of an integration agreement, since the reform of 2011, specified by two modules, dealt with the expenses to be refunded by the Austrian Federation and ruled on the basic requirements for the offered courses.

\section{THE SCOPE OF THE AUSTRIAN INTEGRATION ACT 2017 IN GENERAL}

$\S 1$ para 1 of the Integration Act defines as the objective of the law "to quickly integrate persons who are legally resident in Austria into Austrian society by systematically offering integration measures (the promotion of integration) and by means of the obligation to actively participate in the integration process." The persons addressed by the act have an obligation to integrate.

$\S 2$ para 2 defines the term "integration". The Act narrows the personal scope of the application of its major provisions to Convention refugees, non-Austrian citizens holding subsidiary protection status under the Austrian Asylum Act and to non-EU citizens entitled to permanent residence in Austria ( $\$ 3)$.

As to the integration measures, the Act differentiates according to its personal scope. For Convention refugees and persons holding subsidiary protection status, these measures are promotion of language learning and orientation, which means German courses and values and orientation courses ( $\S 4-5$ Austrian Integration Act 2017). For these persons the Act requires an integration declaration instead of an integration agreement. The persons must comply with the fundamental values of the legal and social systems and are obliged to fully participate in, cooperate with regard to, and complete the courses mentioned above ( $\$ 6$ para 1$)$. The legal basis for the obligation to sign the integration declaration follows from $\S 67$ para 1 Austrian Asylum Act 2005 which obliges them once they have been granted their status immediately to appear in person at the integration center competent for the federal province where they are residing. The integration centers are set up by the Austrian Integration Fund. Non-compliance leads to financial sanctions.

Citizens of non-EU countries entitled to permanent residence in Austria have to sign an integration agreement ( $\S 7$ para 1$)$. Under this agreement they are obliged to acquire German language skills and knowledge of the democratic system and the fundamental principles derivable from it. The integration agreement is set up by two sequential modules. Module 1 aims at providing German language skills for the purpose of advanced basic language usage at A2 language level pursuant to the Common European Framework of Reference for Languages and at obtaining knowledge of the fundamental values of the legal and social systems. Module 2 leads to advanced language knowledge 
at B1 level and to advanced knowledge of the fundamental values of the legal and social systems ( $§ 7$ para 2$)$.

Compliance with module 1 must be given upon first time granting of a residence permit ( 99 para 1). The Act sets specific deadlines for fulfilment of this requirement. The fulfilment is achieved by the successful completion of an integration exam or equivalent or comparable certificates enumerated by $\S 9$ para 4 Austrian Integration Act 2017. $\S 9$ para 5 grants exceptions, for example for minors or physically or mentally ill persons. A certificate of having completed module 1 which is not older than two years upon submission is a requirement for renewal of the residence permit ( $\$ 9$ para 7).

The privileged status as permanent EU resident ( $\$ 45$ Austrian Settlement and Residence Act 2005) requires the completion of module 2, which is documented either by a respective integration exam or by equivalent or comparable qualifications. A similar exception as for module 1 exists for minors or physically or mentally ill persons $(\S 10$ para 3 Austrian Integration Act 2017).

$\S \S 11$ and 12, respectively, define the elements of an integration exam for module 1 or module 2. Specific integration courses ( $§ 13)$ assist in the preparation for the integration exams which are subsidized from federal funds (§14).

In addition, integration promotion can be provided to citizens of non-EU countries entitled to permanent residence in Austria ( $§ 16)$.

The providers of integration measures are subject to a reporting system $(\S 15)$.

On the institutional side, an Expert Council for Integration and an Advisory Committee on Integration have been established. The role of the Expert Council is to advise the competent Minister, to provide for assistance in the implementation of a National Action Plan for Integration and the relevant strategies and for elaboration and publishing of an annual integration report ( $\$ 18)$.

The Advisory Committee on Integration promotes the comprehensive exchange of knowledge, information and opinions on integration issues of general significance and contributes to networking across competences ( $\S 19$ and 20$)$. On the ministerial level, integration monitoring, including use of data on asylum and residence, school education and adult education, social benefits, the labor market, German courses, values and orientation courses, and academic research is set up (\$21). A Research Coordination Office on the ministerial level complements gaining comprehensive academic knowledge of the integration of persons without Austrian citizenship ( $\$ 22)$.

The observance of the Austrian Integration Act 2017 is guaranteed by sanctions provided by $\S 23$ of the Act, which consist of a scale of fines or even imprisonment of up to three weeks. The indirect sanctions linked to lack of relevant integration in the Austrian Asylum Act 2005 and in the Austrian Aliens Police Act 2005 may well have a stronger effect on obedience than the sanctions according to the Integration Act itself. The sanctions according to the Austrian Integration Act extend, however, also to integration service providers and other persons not necessarily subject to the Austrian Asylum Act 2005 or to the Austrian Aliens Police Act 2005. 


\section{CONCEPT OF "INTEGRATION" ACCORDING TO THE AUSTRIAN INTEGRATION ACT 2017}

According to $\S 2$ para 1 Austrian Integration Act "integration" is "a process involving all sections of society, whose success depends on all people living in Austria and is based on personal interaction. Integration requires, in particular, that immigrants actively participate in this process, accept the integration measures offered, and acknowledge and respect the fundamental values of a European democratic country. All state institutions at the federal, provincial and municipal levels must also make their contribution towards a successful integration process by systematically offering integration measures within their areas of competence. Integration as a process involving all sections of society demands concerted action by the various actors of the state and of civil society and requires an active contribution from any individual person in Austria, within that person's possibilities."

Despite the fact that the process of integration is described in this definition as a process including all people in Austria, the obligation actively to contribute to integration is limited to the immigrants. The values they might adhere to are ignored. Immigrants have to recognize the fundamental values of a European democratic country. The explanatory remarks of the Austrian Government to the Austrian Parliament refers to $§ 11$ of the Austrian Citizenship ${ }^{17}$ in this context, ${ }^{18}$ which in fact does, however, nothing more than repeating the same text. The explanatory remarks emphasize that the recognition of the fundamental values of a European democratic country shall express attachment with the fundamental order of Austria as such country and negation of all radical, fundamentalist movements which disagree with this fundamental order. The explanatory remarks underline that a successful integration requires a contribution of all state institutions on whatever level and of all people living in Austria, but neither the remarks, nor the text of the act itself, specify which obligations ensue from such contribution. Apart from organizational and financial subsidy on state level, there is no mention of any corresponding obligations on the side of the Austrian citizens.

The definition clearly expresses a monoculturalist approach as opposed to a multiculturalist, both in the understanding of the theory of Bhikhu Parekh. For Parekh a multicultural society, "then, is one which includes two or more cultural communities. It might respond to its cultural plurality in one of two ways, each of which is in turn capable of taking several forms. It might welcome and cherish the plurality, make it central to its self-understanding, and respect the claims of its cultural communities in its laws and policies; or it might seek to assimilate the diverse cultures into its mainstream culture either wholly or substantially. In the first case it is multiculturalist, and in the second monoculturalist, in its orientation and ethos. Multiculturality refers to the fact of cultural plurality; multiculturalism to a normative response to that fact." 19

17 Re-promulgated by BGBl. Nr. 311/1985 as last amended by BGBl. I Nr. 68/2017.

181586 Blg. NR XXV. GP, p. 2.

19 PAREKH, B.: Political Theory and the Multicultural Society. Radical Philosophy, May/June 1999. Available at: http://red.pucp.edu.pe/wp-content/uploads/biblioteca/081232.pdf (10 February 2018). 
There is no doubt that the understanding of the Austrian society and its problems behind the Austrian Integration Act 2017 results from many cultural communities established as a consequence of migration processes. The Austrian Integration Report 2017, elaborated by the Expert Council for Integration, explains the background and provides the necessary statistical data. A massive increase of refugees, which in the understanding of the Geneva Refugee Convention should mostly be called displaced persons, shocked people in Austria and made them understand that most of these persons might settle permanently in Austria. ${ }^{20}$ Given a total population of 8.8 million inhabitants, in 2015 214,000 and in 2016 174,000 persons immigrated to Austria. Considering the number of emigrants, the net immigration in these two years was $+177,000$ persons. As a result, the share of the population with a migration background in Austria totals about 1.9 million. ${ }^{21}$

The majority of asylum applications according to the asylum statistics 2016 was war-driven, thereby placing Afghanistan first (27.9\%), Syria next (20.7\%) and Iraq third (6.8\%), whereas in the whole EU Syria came first. ${ }^{22}$ In 2015, the comparable numbers in Austria were $28.9 \%$ from Afghanistan, $27.8 \%$ from Syria, and $15.4 \%$ from Iraq. ${ }^{23}$ Scientific research concludes unanimously that the refugee migration will lead to an increase in government spending. The Austrian Expert Council for Integration concludes that realizing positive economic effects from asylum migration would require that persons entitled to asylum would be successfully integrated into the Austrian labor market. If labor market integration is not achieved, negative socio-political effects on Austria also in the long term due to the size of the refugee migration of 2015 will be seen. ${ }^{24}$ In order to achieve the aim of a rapid integration in the labor market, a specific Labor Market Integration Act entered into force on 1 September 2017 for Convention refugees and persons holding subsidiary protection status, and on 1 January 2018 for asylum seekers with a positive decision prognosis. ${ }^{25}$ This act provides for an integration year for these persons as a specific labor-market-oriented measure. Convention refugees and persons with a subsidiary protection status who are unemployed, once their status has been granted, are obliged to undergo the course offer run by the Austrian Labor Market Service within this integration year ( $\$ 3$ para 2 ), and asylum seekers are entitled to participate in this program ( $\$ 3$ para 3 ) which aims at assisting them in easier access to jobs.

As of 1 January 2017, the foreign resident population totaled 1,341,930 persons. 677,201 of them or $50.5 \%$ were non-EU citizens, 664,729 or $49.5 \%$ were EU or EFTA citizens. ${ }^{26}$ The largest groups of non-EU citizens entitled to permanent residence were Serbian $(118,454)$, Turkish $(116,838)$ and citizens from Bosnia and Herzegovina $(94,611) .{ }^{27}$ Most of them are migrant workers (in Austria called "guest workers") who

20 Austrian Integration Report 2017. Vienna 2017. Available at: https://www.bmeia.gv.at/en/integration /integration-report/ (10 February 2017).

21 See Austrian Integration Report 2017 (fn. 20), p. 7.

22 See Austrian Integration Report 2017 (fn. 20), p. 21.

23 See Austrian Integration Report 2017 (fn. 20), p. 24.

24 See Austrian Integration Report 2017 (fn. 20), p. 37.

25 BGBl. I Nr. 75/2017.

${ }^{26}$ See Austrian Integration Report 2017 (fn. 20), p. 71.

27 See Austrian Integration Report 2017 (fn. 20), p. 71. 
came to Austria starting in the 1960 s, and their descendants. ${ }^{28}$ Surveys show that the emotional attachment within these groups to Austria has increased over the last six years, but of all these groups persons of Turkish origin have the weakest attachment to Austria. ${ }^{29}$ The Austrian Integration Report identifies the low employment rate for women who are first or second generation immigrants as the key issue for their integration, because it considers participation in the labor market as a key for participation in the society. ${ }^{30}$

Within the group of EU/EFTA immigrants, the majority is German citizens $(181,615$ persons at the beginning of the year 2017). However, Romanians have been overtaking the annual immigration plus and are coming second now (92,095 persons). The third place is taken by Croatians $(73,334) .{ }^{31}$ A comparison of the last eleven years shows an increase of immigrants from the old EU member states by $83.2 \%$ and from the new EU member states by $137.4 \%{ }^{32}$ Given the different economic, social and education background of persons immigrating from these two different zones to Austria, the Expert Council on Immigration sees a need to focus in research and monitoring also on these groups from the point of view of their integration into the Austrian society. ${ }^{33}$

There is only one chapter in the Austrian Integration Report 2017 which deals with the other part of the Austrian society and its contribution to integration of any kind of immigrants as part of the two-sided-process of integration. It is chapter 1.4.5 dealing with "Field of action intercultural dialogue". 34 The Report summarizes this field of action as follows:

"Integration is a reciprocal process, thus a dialogue between people with different traditions, opinions and religious attitudes is necessary for the integration process. Such a dialogue must take place on the basis of the Austrian and European values, should promote mutual understanding and prevent radicalisation processes. The $50 \mathrm{Ac}-$ tion Points include a wide range of concrete measures that are not aimed primarily at refugees and their specific integration challenges, but contain many topics of general relevance for the integration discourse. In particular, the 50 Action Points focus on strengthening preventive measures against radicalisation, the promotion of an Islam of a European notion and actions against racism, anti-Semitism and Islamophobia." 35

The summary makes clear that the monoculturalist approach so far has been set up as a one-way street and, even when it comes to intercultural dialogue, focuses on the various immigrant groups and their mutual relationships. If, as has been done in the context of the Afghanistan, Iraq and Syrian wars, the approach to hate postings, radicalisation of Islam, and anti-Semitism simply from the perspective of Austrian and European values, means to ignore the contribution Europe had to these wars and to the ensuing radicalisation of Islam, hate between religions and consequently between groups of the Austrian

28 See Austrian Integration Report 2017 (fn. 20), p. 70.

29 See Austrian Integration Report 2017 (fn. 20), p. 73.

30 See Austrian Integration Report 2017 (fn. 20), pp. 74-75.

31 See Austrian Integration Report 2017 (fn. 20), p. 80.

32 See Austrian Integration Report 2017 (fn. 20), p. 81.

33 See Austrian Integration Report 2017 (fn. 20), p. 85.

34 See Austrian Integration Report 2017 (fn 20,), pp. 52-55 and 66.

35 See Austrian Integration Report 2017 (fn. 20), p. 52. 
immigration society will increase. It is understandable that a monoculturalist instead of a multiculturalist approach is the reaction for Europe and Austria, feeling threatened by radicalisation of religions and undermining of the autochthonous society. As long as this process does not, however, touch on the reasons and origins of these tendencies, but confines the analysis merely to their consequences, the monoculturalist approach is at risk of failing as did the multiculturalist before. Europe's role in the Near and Middle East and beyond needs to be reconsidered as the other part of the "reciprocal process" and as a part of "Austrian and European values".

Ao. Univ.-Prof. Dr. Michael Geistlinger

Universität Salzburg

michael.geistlinger@sbg.ac.at 